\section{ABCS}

How to cite this article: Silva et al. The influence of body composition on the motor capacities of first-year university students from Physical Education program. ABCS Health Sci. 2020;45:e020019. https:// doi.org/10.7322/abcshs.45.2020.1331

Received: Oct 17, 2019

Revised: Jan 12, 2020

Approved: Mar 26, 2020

Corresponding author: Siomara Aparecida da Silva - Universidade Federal de Ouro Preto, Escola de Educação Física - Rua Dois, 110, sala 27 - CEP: 35400-000 - Ouro Preto (MG), Brasil -

E-mail: siomarasilva.lamees@gmail.com

Declaration of interests: nothing to declare

This is an open access article distributed under the terms of the Creative Commons Attribution License

(C) 2020 Silva et al.

\title{
The influence of body
} composition on the motor capacities of first-year university students from Physical Education course

\author{
César Milagres da Silva1, Thiago da Costa Barros ${ }^{1}$, Siomara Aparecida da Silva ${ }^{1}$ \\ ${ }^{1}$ Escola de Educação Física, Universidade Federal de Ouro Preto (UFOP) - Ouro Preto (MG), Brasil.
}

\begin{abstract}
Introduction: University entrance is a milestone in behavior change for young people. Changes that occur during university attendance are crucial for a healthy adult life. Worldwide high rates of obesity and low levels of physical activity are worrying, and they are related to motor coordination, which is a predictor of sustained motor practice. Objective: To analyze the influence of body composition on the motor skills of incoming university students. Methods: 137 university students of the program in Physical Education (21.8 \pm 3.6 years) took part in the study. Body composition (body mass index, percentage of fat, waist/hip ratio), motor coordination without/with ball (KTK and TECOBOL-short tests), and physical fitness tests (PROESP-br) were analyzed through descriptive statistics, t-student test and Pearson correlation. The statistical significance was $\mathrm{p} \leq 0.05$. Results: Comparisons between sexes revealed differences in the physical and motor tests, with the exception of the sit-and-reach tests and the balance beam. There was correlation between body composition and both physical and motor tests. Moreover, the percentage of fat was correlated with cardiorespiratory fitness tests $(r=-0.769 ; \mathrm{p} \leq 0.001)$, lower limb strength $(\mathrm{r}=-0.710 ; \mathrm{p} \leq 0.001)$, upper limb strength $(\mathrm{r}=-0.604 ; \mathrm{p} \leq 0.001)$, velocity $(\mathrm{r}=0.672$; $\mathrm{p} \leq 0.001)$, and dribble of TECOBOL $(\mathrm{r}=0.502 ; \mathrm{p} \leq 0.001)$. Conclusion: Motor skills are related to body composition indicators in young university students who engaged in Physical Education program.
\end{abstract}

Keywords: cardiorespiratory fitness; body composition; overweight; motor skills; muscle strength.

\section{INTRODUCTION}

Overweight and obesity ${ }^{1}$ continuously increase throughout Brazil. One of the factors that contributes to this result is the permanence of sedentary behavior ${ }^{2}$. This factor is a constant interest of investigations by health professionals, due to its influence on motor capacity and body composition. In this context, the study of Sport Practices and Physical Activity, carried out by the Brazilian agency for statistical information (Instituto Brasileiro de Geografia e Estatitica, IBGE) in partnership with the national Ministry of Sport, revealed that 6 out of 10 people (62.1\%) aged 15 years and older do 
not practice physical activities or sports in the country, mainly due to the lack of time and interest. According to the same study, more than 100 million people are sedentary in Brazil ${ }^{3}$.

The practice of physical and/or sports activities is related to the quality of life, since it promotes the improvement of the fitness, wellness and health ${ }^{4}$. However, due to technological advances, which have facilitated the routine activities, people have adopted a hypokinetic lifestyle with great reduction in motor performance for everyday actions ${ }^{5}$. The limitation of movements associated with inappropriate eating habits contributes to the increase in cases of malnutrition, overweight and obesity ${ }^{6}$. These factors can impair the performance of motor skills such as flexibility, strength, speed, endurance and motor coordination, affecting the development of motor skills in children, young people and adults ${ }^{7}$.

Throughout elementary education cycles, young people should have their motor skills and abilities developed to support the diversity of sports practices available for leisure, health, performance, aesthetics ${ }^{8,9}$. Young people at the university live a landmark of behavior change that uses the motor base built in childhood and youth. The changes that occur in the university stage are decisive for a healthy adult life $\mathrm{e}^{10}$. Few studies address the prevalence of physical inactivity and its effects among university students ${ }^{11,12}$. Studying intervening factors in this stage ${ }^{4,13}$ is relevant to an active and healthy adult life. Thus, the aim of this study was to analyze the influence of body composition on the motor capacity of young people recently admitted to university.

\section{METHODS}

This is a cross-sectional study in which variables of body composition, anthropometric measurements, physical fitness and motor capacity of young academics from the Federal University of Ouro Preto, Minas Gerais, Brazil were analyzed.

\section{Sample}

The participants were students from the first semester of Physical Education courses (bachelor and teaching degree) referring to the semesters of 2016, 2017 and the first semester of 2018. The sample consisted of 137 volunteer university students, aged $21.8 \pm 3.6$ years, being 80 male and 57 female, 76 were from the Bachelor's degree and 61 from the teaching degree. The project was approved by the instuticional Research Ethics Committee (CAAE 20383013.7.0000.5150).

\section{Procedures}

Body mass index $(\mathrm{BMI})$, fat percentage $(\% \mathrm{~F})$ with different protocols for men ${ }^{14}$ and women ${ }^{15}$, and the waist/hip ratio (WHR) were used to assess body composition. The body mass of each participant was obtained using a manual scale, with a resolution of
100 grams. For height measurement, a $200 \mathrm{~cm}$ wall stadiometer with $0.1 \mathrm{~mm}$ precision scale was used.

The PROESP-BR ${ }^{16}$ protocol was administered for testing physical/motor skills. This battery consists of seven tests: 1) Flexibility: sit and reach, using the "Wells Bench" the result is measured in centimeters from the most distant position that the student can reach on the scale with the fingertips; 2) Abdominal endurance: the result is expressed by the number of complete abs (touching elbows on thighs) performed in 60 seconds; 3 ) Strength of lower limbs: horizontal jump, at the signal the student should jump as far as possible landing with both feet simultaneously. Two attempts were made, the best result will be considered for evaluation purposes; 4) Strength of the upper limbs: throw of "medicine ball", throw the ball as far as possible, keeping your back against the wall. The throw distance was recorded from the zero point to the place where the ball first hit the ground. The best result out of two attempts was recorded for evaluation purposes; 5) Agility: the student must run at full speed and touch with one hand the bottle located in the diagonal corner of the square (crossing the square); 6) Speed: $20 \mathrm{~m}$ race, at the appraiser's signal, the student must move as quickly as possible towards the finish line; and 7) Cardiorespiratory fitness: participants were divided into groups in order to fit in the dimensions of the track. Students were informed about the test, emphasizing that they should run as long as possible for 9 minutes, avoiding speed peaks interspersed with long walks.

Body motor coordination was analyzed by means of the Körperkoordinations Test für Kinder (KTK) test battery by Kiphard and Schilling ${ }^{17}$, which is composed of four tests: balance beams (BB), monopedal jumps (MJ), lateral jumps (LJ) and lateral transfer on platform (TP). For the motor coordination with the ball, it was applied the test of coordination with ball (TECOBOL) proposed by Silva ${ }^{18}$. TECOBOL consists of a battery with basic skills in situations of pressure of the conditioning of collective games'motor actions. The test assesses skills with ball transport (dribbling and conducting) and hitting the target (launch and kick).

\section{Statistical Analysis}

Data analysis was performed using SPSS version 23 software with medium and dispersive descriptive results. The normality and sphericity of the data were tested by the Shapiro-Wilk test. The comparison of two measurements was performed using the Student's t-test. Pearson's correlation was used to verify the relationship between physical fitness, motor coordination and body composition. Negative or positive correlations were considered above 0.9 , a very strong correlation, 0.7 to 0.9 indicate a strong correlation, 0.5 to 0.7 a moderate correlation, 0.3 to 0.5 a weak correlation, 0.0 to 0.3 positive or negative indicate a despicable correlation, according to Mukaka ${ }^{19}$. In all situations, the significance adopted was $\mathrm{p} \leq 0.05$. 


\section{RESULTS}

The general description (Table 1) presents a characterization of the profile of university student. Of the study variables, only monopedal and lateral jumps do not present normative tables by sex separation (Table 1).

The results presented in Table 2 refer to the comparison of the means and standard deviation of university students according to sex in anthropometric batteries, PROESP-BR, TECOBOL, KTK. It is observed that only in the tests of sitting and reaching and balance beam, there were no statistically significant differences (Table 2).

When comparing the sexes, male students showed significant differences in physical tests (cardiorespiratory fitness, explosive strength in the lower and upper limbs, agility, speed, abdominal resistance) compared to the female.

For the total sample, a correlational analysis was made between body composition indexes (BMI, fat percentage and waist/hip ratio), physical capacity (PROESP-br), motor coordination (KTK) and coordination motor with ball (TECOBOL-short). There were moderate and significant correlations between: the percentage of fat and physical fitness, strength of upper and lower limbs, speed and dribbling; and the waist/hip ratio and the strength of the upper limbs (Table 3).

Table 1: Characterization of the incoming university profile, minimum, maximum and average values and standard deviation $(n=137)$.

\begin{tabular}{|c|c|c|c|}
\hline Variables & Minimum & Maximum & Mean \pm SD \\
\hline Age (years) & 18 & 35 & $21.8 \pm 3.6$ \\
\hline Body mass (Kg) & 45.5 & 108.9 & $68.21 \pm 12.57$ \\
\hline Height (cm) & 149.2 & 195 & $170.4 \pm 9.11$ \\
\hline BMI $\left(\mathrm{Kg} / \mathrm{m}^{2}\right)$ & 16.91 & 33.22 & $23.37 \pm 3.19$ \\
\hline Porcentage of fat (\%F) & 3.51 & 36.53 & $17.14 \pm 8.67$ \\
\hline WHR & 0.64 & 0.95 & $0.77 \pm 0.06$ \\
\hline Flexibility (Sit and Reach) & 9 & 47 & $28.92 \pm 8.25$ \\
\hline $\begin{array}{l}\text { Cardiorespiratory fitness } \\
\text { (9 min) }\end{array}$ & 765 & 2373 & $1601.1 \pm 276.93$ \\
\hline $\begin{array}{l}\text { Explosive strength of } \\
\text { lower limbs }(\mathrm{cm})\end{array}$ & 74 & 274.2 & $182.2 \pm 40.91$ \\
\hline $\begin{array}{l}\text { Explosive strength of } \\
\text { upper limbs }(\mathrm{cm})\end{array}$ & 265 & 763 & $503.2 \pm 130.2$ \\
\hline Agility (s) & 5 & 9.3 & $6.48 \pm 0.84$ \\
\hline Speed (s) & 2.78 & 5 & $3.55 \pm 0.46$ \\
\hline $\begin{array}{l}\text { Abdominal (number of } \\
\text { repetitions) }\end{array}$ & 13 & 62 & $40.75 \pm 9.77$ \\
\hline KTK balance beam & 15 & 72 & $53.31 \pm 12.49$ \\
\hline KTK monopedal jump & 34 & 78 & $63.8 \pm 9.9$ \\
\hline KTK side heels & 32 & 111 & $75.5 \pm 14.5$ \\
\hline KTK platform transfer & 24 & 70 & $45.5 \pm 11.0$ \\
\hline TECOBOL launch(s) & 11 & 39 & $17.93 \pm 5.09$ \\
\hline TECOBOL kick (s) & 18 & 123 & $49.06 \pm 20.27$ \\
\hline TECOBOL drible (s) & 23 & 95 & $46.32 \pm 15.10$ \\
\hline TECOBOL conduction (s) & 29 & 106 & $53.99 \pm 15.79$ \\
\hline
\end{tabular}

Legend: BMI: body mass index; WHR: waist/hip ratio; SD: standard deviation.
Table 2: Comparison between sexes in anthropometric batteries, PROESP-Br, TECOBOL, KTK $(n=137)$.

\begin{tabular}{|c|c|c|}
\hline Variables & $\begin{array}{c}\text { Male } \\
\text { (Mean } \pm \text { SD) }\end{array}$ & $\begin{array}{c}\text { Female } \\
(\text { Mean } \pm \text { SD) }\end{array}$ \\
\hline Age (years) & $22.0 \pm 3.5$ & $21.5 \pm 3.7$ \\
\hline Body mass $(\mathrm{Kg})$ & $74.3 \pm 11.4^{*}$ & $59.7 \pm 8.6^{*}$ \\
\hline Stature $(\mathrm{cm})$ & $175.6 \pm 6.8^{*}$ & $163.1 \pm 6.7^{\star}$ \\
\hline $\mathrm{BMI}\left(\mathrm{Kg} / \mathrm{m}^{2}\right)$ & $24.0 \pm 3.2^{*}$ & $22.4 \pm 3.0^{*}$ \\
\hline Fat percentage (\%F) & $11.6 \pm 5.9^{*}$ & $24.9 \pm 5.2^{*}$ \\
\hline WHR & $0.82 \pm 0.0^{*}$ & $0.72 \pm 0.0^{*}$ \\
\hline Flexibility (Sit and Reach) & $28.2 \pm 8.0$ & $29.9 \pm 8.6$ \\
\hline Cardiorespiratory Fitness (9 min) & $1754.9 \pm 226.6^{*}$ & $1385.1 \pm 180.4^{*}$ \\
\hline Lower Limbs Explosive Force (cm) & $206.4 \pm 31.1^{*}$ & $148.4 \pm 26.6^{*}$ \\
\hline $\begin{array}{l}\text { Explosive Strength of Upper } \\
\text { Limbs }(\mathrm{cm})\end{array}$ & $594.6 \pm 82.8^{*}$ & $374.9 \pm 52.8^{*}$ \\
\hline Agility (s) & $6.12 \pm 0.63^{*}$ & $6.99 \pm 0.85^{\star}$ \\
\hline Speed (s) & $3.29 \pm 0.30^{*}$ & $3.92 \pm 0.39^{*}$ \\
\hline Abdominal (number of repetitions) & $44.3 \pm 8.9^{*}$ & $35.7 \pm 8.7^{\star}$ \\
\hline KTK Balance beam & $52.4 \pm 12.8$ & $54.4 \pm 8.8$ \\
\hline KTK Monopedal Jump & $66.0 \pm 7.9^{*}$ & $60.8 \pm 9.4^{*}$ \\
\hline KTK Side Heels & $79.2 \pm 12.2^{*}$ & $70.6 \pm 12.9^{*}$ \\
\hline KTK Platform Transfer & $47.0 \pm 10.4^{*}$ & $43.0 \pm 9.1^{*}$ \\
\hline TECOBOL launch (s) & $16.15 \pm 3.56^{*}$ & $20.29 \pm 5.86^{*}$ \\
\hline TECOBOL kick (s) & $41.34 \pm 16.04^{*}$ & $59.26 \pm 20.99^{*}$ \\
\hline TECOBOL dribble (s) & $39.51 \pm 8.23^{*}$ & $55.32 \pm 17.38^{*}$ \\
\hline TECOBOL conduction (s) & $46.98 \pm 8.48^{*}$ & $63.26 \pm 18.39^{*}$ \\
\hline
\end{tabular}

Legend: BMI: body mass index; WHR: waist/hip ratio; SD: standard deviation ${ }^{*}$ Significant differences between both sexes $(p<0.05)$.

Table 3: Correlation between BMI, porcentage of fat, waist/hip ratio with physical fitness.

\begin{tabular}{|c|c|c|c|}
\hline $\begin{array}{l}\text { PROESP-br, KTK and } \\
\text { TECOBOL variables }\end{array}$ & BMI & $\% F$ & WHR \\
\hline \multirow{2}{*}{ Flexibility (Sit and Reach) } & $\mathrm{p}=0.690$ & $p=0.638$ & $p=0.159$ \\
\hline & $r=-0.034$ & $r=-0.041$ & $r=-0.064$ \\
\hline \multirow{2}{*}{ Cardiorespiratory fitness (9 $\mathrm{min}$ ) } & $p=0.100$ & $\mathrm{p} \leq 0.001$ & $p \leq 0.001$ \\
\hline & $r=-0.141$ & $r=-0.769^{*}$ & $r=0.445$ \\
\hline \multirow{2}{*}{$\begin{array}{l}\text { Strength of the lower limbs } \\
\text { (horizontal jumps) }\end{array}$} & $p=0.758$ & $\mathrm{p} \leq 0.001$ & $\mathrm{p} \leq 0.001$ \\
\hline & $r=-0.027$ & $r=-0.710^{*}$ & $r=0.470$ \\
\hline \multirow{2}{*}{$\begin{array}{l}\text { Strength of the upper limbs } \\
\text { (medicineball pitch) }\end{array}$} & $p \leq 0.001$ & $p \leq 0.001$ & $p \leq 0.001$ \\
\hline & $r=0.345$ & $r=-0.604^{*}$ & $r=0.655^{*}$ \\
\hline \multirow{2}{*}{ Agility (square) } & $p=0.769$ & $\mathrm{p} \leq 0.001$ & $p \leq 0.001$ \\
\hline & $r=-0.025$ & $r=0.467$ & $r=-0.332$ \\
\hline \multirow{2}{*}{ Speed (running) } & $p=0.643$ & $\mathrm{p} \leq 0.001$ & $p \leq 0.001$ \\
\hline & $r=0.040$ & $r=0.672^{*}$ & $r=-0.469$ \\
\hline \multirow{2}{*}{ Abdominal strength (quantity) } & $p=0.604$ & $p \leq 0.001$ & $p \leq 0.001$ \\
\hline & $r=0.045$ & $r=-0.435$ & $r=0.276$ \\
\hline \multirow{2}{*}{ KTK - Balance beam } & $p \leq 0.001$ & $p=0.247$ & $p=0.190$ \\
\hline & $r=-0.310$ & $r=-0.110$ & $r=-0.125$ \\
\hline \multirow{2}{*}{ KTK - Monopedal jump } & $p=0.074$ & $p=0.005$ & $p \leq 0.001$ \\
\hline & $r=0.443$ & $r=-0.265$ & $r=0.355$ \\
\hline \multirow{2}{*}{ KTK - Side heels } & $p=0.028$ & $p \leq 0.001$ & $p=0.003$ \\
\hline & $r=-0.208$ & $r=-0.428$ & $r=0.282$ \\
\hline \multirow{2}{*}{ KTK - Platform transfer } & $p=0.258$ & $\mathrm{p} \leq 0,001$ & $p=0.228$ \\
\hline & $r=-0.158$ & $r=-0.352$ & $r=0.115$ \\
\hline \multirow{2}{*}{ TECOBOL - Launch } & $p=0.067$ & $p=0.013$ & $p=0.069$ \\
\hline & $r=-0.217$ & $r=0.291$ & $r=-0.216$ \\
\hline
\end{tabular}


Table 3: Continuation.

\begin{tabular}{|l|c|c|c|}
\hline $\begin{array}{l}\text { PROESP-br, KTK and } \\
\text { TECOBOL variables }\end{array}$ & BMI & $\% F$ & WHR \\
\hline TECOBOL - Kick & $\mathrm{p}=0.251$ & $\mathrm{p}=0.004$ & $\mathrm{p}=0.003$ \\
\hline TECOBOL - Dribble & $\mathrm{r}=-0.137$ & $\mathrm{r}=0.333$ & $\mathrm{r}=-0.349$ \\
\hline TECOBOL - Conduction & $\mathrm{p}=0.339$ & $\mathrm{p} \leq 0.001$ & $\mathrm{p} \leq 0.001$ \\
\hline & $\mathrm{r}=-0.114$ & $\mathrm{r}=0.500^{*}$ & $\mathrm{r}=-0.451$ \\
\hline & $\mathrm{p}=0.152$ & $\mathrm{p} \leq 0.001$ & $\mathrm{p} \leq 0.001$ \\
\hline
\end{tabular}

Legend: BMI: body mass index; \%F: percentage of fat; WHR: waist/hip ratio. ${ }^{*}$ Correlations above 0.5 with $p<0.05$.

When performing the Person correlation by sex, a moderate $(r=-0.610)$ and significant $(p \leq 0.001)$ value was found between cardiorespiratory fitness and the percentage of fat in males. In females, no moderate and significant correlations were found.

\section{DISCUSSION}

Corroborating studies in the area of motor development, as shown in Table 2, women showed significant differences in relation to men in the anthropometric profile (body mass, height, BMI, \%F, WHR), and in motor batteries. Furthermore, except in the flexibility tests and balance beam there were no significant differences between genders. Greater flexibility is usually associated with women and their values are significantly different among $m^{20}{ }^{20}$. However, in this study women did not present significantly greater values in comparison to men, despite achieving great values, as much as in the KTK balance beam. For BMI and WHR, women presented higher and significant values in relation to men.

Regarding the percentage of fat, men in this study had an average of $11.6 \%$ and women $24.9 \%$. In Brazil, values of university students in the state of São Paulo showed similar results, with men averaging $10.5 \%$ and women $23.8 \%{ }^{21}$. Likewise, students from Rio Grande do Sul showed values of $13.8 \%$ for men and $23.9 \%$ for women $^{12}$ (Table 2).

In a study ${ }^{22}$ with 100 young people between 11 and 14 years old, of both sexes, boys showed higher values in all variables of the PROESP-BR test compared to girls, except in the abdominal and flexibility tasks. This difference is due to the relationship between boys having greater lean mass and body volume. In the first years of elementary school, the difference is the same ${ }^{20}$.

In the correlation between the anthropometric profile (BMI,\% G and WHR) with physical fitness (PROESP-BR, TECOBOLshort and KTK), according to Table 3, the percentage of fat showed significant correlations with cardiorespiratory fitness $(\mathrm{r}=0.769)$, lower limb strength $(r=0.710)$, upper limb strength $(r=0.604)$ and speed $(r=0.672)$. In a longitudinal study on the relationships of motor coordination, body fat and physical fitness, it was found that these are reciprocal, the higher the level of physical fitness and motor coordination, the lower the percentage of fat ${ }^{23}$.
Adequate stimulation of motor coordination skills can facilitate the performance of more complex tasks in social and/or sports life. However, an inadequate stimulation of motor coordination, such as a reduction in the practice of physical activities, can result in less efficiency in the performance of daily functional activities, additionally contributing to the gain of body fat mass.

Therefore, the practice of physical activity is also essential to have an adequate body composition, especially for the percentage of fat. This directly interferes with physical fitness, as shown in Table 3, in which it correlates with cardiorespiratory tests, upper limb strength, lower limb strength and speed (Table 3).

In a study ${ }^{24}$ with young people between 10 and 16 years old, before entering university, when correlating BMI with cardiorespiratory fitness (Cooper test 12 minutes) found a negative $(\mathrm{r}=-0.233)$ and significant $(\mathrm{p} \leq 0.001)$ correlation, as well as in the abdominal strength test $(\mathrm{p} \leq 0.001 ; \mathrm{r}=-0.242)$. In the present study, BMI showed a significant correlation with the balance beam test $(\mathrm{p} \leq 0.001 ; \mathrm{r}=-0.310)$ and with the upper limb strength test $(\mathrm{p} \leq 0.001$; $\mathrm{r}=-0.310$ ), although weak, indicating that the greater BMI, the greater the strength of the upper limbs and the lower the balance.

Lima et al. ${ }^{25}$ analyzed the level of physical fitness and physical activity of adolescents (15 to 18 years old), performed the correlation between BMI, flexibility, abdominal resistance, cardiorespiratory fitness and level of physical activity. Despite the results of the study, no moderate relationship was found between the variables, but abdominal resistance showed a weak $(r=0.388)$ and significant $(\mathrm{p}<0.004)$ relationship.

Triani et al. ${ }^{26}$, verified the correlation between $\mathrm{VO}_{2 \max }, \mathrm{BMI}$ and muscle power (strength of the lower limbs) with 16 physical education students, corroborating the studies that found a weak relationship with no significant difference between horizontal jumps and the BMI. The results show that the relationship between BMI and physical fitness tests is weak, so it is understood that BMI is not a measure that represents the individual's physical fitness.

By correlating the anthropometric profile with the tests of body coordination and ball, the percentage of fat showed significant correlations between the motor tests, but this correlation was moderate only in the TECOBOL dribble test $(r=0.502)$.

BMI did not show any correlation with motor coordination with/without ball in university students with an average of 21.8 years. Studies indicate that this relationship also occurs in childhood, the performance of gross motor skills is not related to body composition or anthropometric characteristics ${ }^{27}$. Likewise, balance does not present significant relationships with $\mathrm{BMI}^{28}$.

Ávila and Pérez ${ }^{6}$, while investigating motor coordination problems and the relationship with the percentage of fat with students aged 11 to 12 years, found a significant relationship, with children with locomotor problems having a higher percentage of body fat.

In a study ${ }^{29}$ with young people in athletics practices (11 to 12 years old) through the KTK test and BMI, there was a negative 
and significant correlation, with differences between young people with excess weight in relation to those within the normal range. Through a meta-analysis with systematic review of studies with children and adolescents, Luz et al..$^{30}$ found a low relationship between BMI and KTK, but there is a tendency for a positive relationship between low performance of KTK with higher BMI values. Such results may be the result of a lack of adequate instruction, experience and motivational factors ${ }^{8,31}$.

The present study has a limitation in relation to a motor coordination test (KTK), as it was developed to assess children and adolescents, and is therefore not the most suitable for the research sample. However, considering that university students are recent high school graduates, this fact leads to the approximation of the age group of adolescents by the motor level.

This limitation of the instrument underlies another one, which is the lack of study that seeks to understand the correlations between body composition and motor coordination of young people. In this study, this same situation is addressed as a justification for carrying out these analyzes for their understanding.

When correlating motor skills with motor coordination, it was noticed that body coordination showed significant correlations greater than 0.50 between speed $(r=0.553)$ and strength of lower limbs $(r=0.580)$ with lateral jumps. In motor coordination with the ball, which requires a greater requirement of motor skills, it has significant correlations above 0.50 . These were between: upper limb strength with lauch $(\mathrm{r}=0.521)$; kick $(\mathrm{r}=0.542)$; dribble $(\mathrm{r}=0.544)$; conduction $(\mathrm{r}=-0.583)$. Dribble and conduction skills are also correlated, above 0.50 , with speed (dribble $r=0.652$; conduction $\mathrm{r}=0.662$ ), agility (dribble $\mathrm{r}=0.670$; conduction $\mathrm{r}=0.528$ ) and strength of upper limbs (dribble $\mathrm{r}=-0.555$; conduction $\mathrm{r}=-0.570$ ).

Individuals with low motor coordination are less active than subjects with normal motor coordination ${ }^{32}$, as it hinders their involvement in everyday activities, sports and exercises ${ }^{33}$. Consequently, they end up not enjoying the benefits that the practice of physical activity can provide ${ }^{6}$, thus putting the development of motor capacity and physical conditioning at risk.

It is added that well-trained motor coordination is a predictor for the practice of physical and sporting activities to be consistent and progressive during the school period and throughout life $^{34}$. When the individual responds well to training stimuli, he or she tends to become more actively involved in physical or sports practices.

The BMI and waist/hip ratio tests used to assess body composition did not have significant correlations with the physical and motor fitness tests, whereas the fat percentage showed significant correlations with the physical fitness tests. Thus, results of the present study indicate that motor skills are related to indicators of body composition in young people entering the physical education course, and among motor skills, motor coordination is the one that presents the most interfering values in physical fitness.

\section{ACKNOWLEDGEMENTS}

To the members of the Sports Teaching Methodology Laboratory (LAMEES).

\section{REFERENCES}

1. Tardido AP, Falcão MC. $O$ impacto da modernização na transição nutricional e obesidade. Rev Bras Nutr Clin. 2006;21(2):117-24.

2. Organização das Nações Unidas (ONU). Relatório de Desenvolvimento Humano Nacional - Movimento é Vida: atividades físicas e esportivas para todas as pessoas. Brasília: PNUD, 2017.

3. Instituto Brasileiro de Geografia e Estatística (IBGE). Práticas de esporte e atividade física: 2015. Rio de Janeiro: IBGE, 2017.

4. Mendes-Netto RS, Silva CS, Costa D, Raposo OFF. Nível de atividade física e qualidade de vida de estudantes universitários da área de saúde. Rev Atenção Saúde. 2013;10(34):47-55. https://doi.org/10.13037/rbcs.vol10n34.1802

5. Kraljević R, Gadžić A, Vučković I. Differences in motor skills of seventh-grade boys and girls. Acta Kinesiol. 2013;7(2):62-6.

6. Ávila EMG, Pérez LMR. Problemas de coordenação motora e percentagem de gordura corporal em alunos escolares. Fit Perf J. 2008;7(4):239-44.

https://dx.doi.org/10.3900/fpj.7.4.239.p

7. Mendonça CP, Anjos LA. Aspectos das práticas alimentares e da atividade física como determinantes do crescimento do sobrepeso/ obesidade no Brasil. Cad Saúde Pública. 2004;20(3):698-709. https://dx.doi.org/10.1590/S0102-311X2004000300006
8. Gallahue D, Ozmun J, Goodway J. Compreendendo o desenvolvimento motor: bebês, crianças, adolescentes e adultos. Porto Alegre: McGraw-Hill, 2013

9. Brasil. Ministério da Educação. Base Nacional Comum Curricular (BNCC). Educação é a base. Brasília: MEC, 2016.

10. Pinho APM, Dourado LCDC, Aurélio RM, Bastos AVB. A transição do ensino médio para a universidade: um estudo qualitativo sobre os fatores que influenciam este processo e suas possíveis consequências comportamentais. Rev Psicol. 2015;6(1):33-47.

11. Quadros TMB, Petroski EL, Santos-Silva DA, Pinheiro-Gordia A The prevalence of physical inactivity amongst Brazilian university students: its association with sociodemographic variables. Rev Salud Pública. 2009;11(5):724-33.

12. Glaner MF, Pires CS, Zinn JL. Diagnóstico da aptidão física relacionada à saúde de universitários. Rev Bras Ativ Fís Saúde. 1998;3(4):35-41. https://doi.org/10.12820/rbafs.v.3n4p35-41

13. Oliveira CS, Gordia AP, Quadros TMB, Campos W. Atividade física de universitários brasileiros: uma revisão da literatura. Rev Atenção Saúde. 2014;12(42):71-7. https://doi.org/10.13037/rbcs.vol12n42.2457 
14. Jackson AS, Pollock ML. Generalized equations for predicting body density of men. Br J Nutri. 1978;40(3):497-504. https://doi.org/10.1079/BJN19780152

15. Jackson AS, Pollock ML. Generalized equations for predicting body density of men. Br J Nutri. 1978;40(3):497-504. https://doi.org/10.1079/BJN19780152.

16. Gaya A, Gaya A. Projeto esporte Brasil: manual de testes e avaliação. Porto Alegre: UFRGS, 2016.

17. Kiphard EJ, Schilling VF. Körper-koordinations-test für kinder KTK: manual Von Fridhelm Schilling. Weinhein: Beltz Test, 1974.

18. Silva SA. Bateria de testes para medir a coordenação motora com bola de crianças e jovens Tese (Doutorado) - Universidade Federal do Rio Grande do Sul. Porto Alegre: 2010.

19. Mukaka M. Statistics corner: A guide to appropriate use of correlation coefficient in medical research. Malawi Med J. 2012;24(3):69-71.

20. Oliveira VM, Brasil MR, Chumlhak Z, Cordel PT, Czuy GHB, Silva SR. Nível de aptidão física em escolares: influência do índice de massa corporal, sexo e quantidade de sono. Saúde Meio Ambient. 2017;6(1):4-17.

https://doi.org/10.24302/sma.v6i1.1382

21. Mesquita CAA, Turi-Lynch BC, Bergoc RD, Maia RL, Amaral SL, Monteiro HL. Aptidão física relacionada à saúde de alunos de graduação em educação física. J Phys Educ. 2018;29(1):e2908. https://dx.doi.org/10.4025/jphyseduc.v29i1.2908

22. Reis MS, Amud GOT, Soares SS, Silva CDC, Corrês LS. Avaliação da aptidão física em jovens de uma escola pública de Manaus. Rev Bras Prescr Fisiol Exercício. 2018;12(72):63-9.

23. Lima RA, Bugge A, Ersbøll AK, Stodden DF, B. Andersen L. The longitudinal relationship between motor competence and measures of fatness and fitness from childhood into adolescence. J Pediatr (Rio J). 2019;95(4):482-8. https://doi.org/10.1016/j.jped.2018.02.010

24. Maziero RSB, Bozza R, Barbosa Filho VC, Piola TS, Campos W. Correlação do índice de massa corporal com as demais variáveis da aptidão física relacionada à saúde em escolares do sexo masculino de Curitiba-PR, Brasil. UNOPAR Cient Ciênc Biol Saúde. 2015;17(1):9-12.

25. Lima FEB, Louvison Junior JN, Pellegrinotti IL, Lima WF, Lima SBS, Lima FB. Relação entre aptidão física e atividade física de adolescentes de 15 a 18 anos da cidade de Jacarezinho/PR. Rev Biomotriz. 2017;11(3):51-62.

26. Triani FS, Lima VP, Correa Neto VG, Monteiro ER. Correlação entre índice de massa corporal, potência muscular e consumo de oxigênio de estudantes de educação física. J Health Sci. 2018;20(1):29-33. https://dx.doi.org/10.17921/2447-8938.2018v20n1p29-33

27. Catenassi FZ, Marques I, Bastos CB, Basso L, Ronque ERV, Gerage AM. Relação entre índice de massa corporal e habilidade motora grossa em crianças de quatro a seis anos. Rev Bras Med Esporte. 2007;13(4):227-30.

https://dx.doi.org/10.1590/S1517-86922007000400003

28. Lemos LFC, David AC, Mota CB. Equilíbrio postural: correlações com desempenho motor e variáveis antropométricas em crianças de 4 a 10 anos de idade. Rev Saúde Desenvolv Humano. 2016;4(1):27-36. https://dx.doi.org/10.18316/2317-8582.16.16

29. Freitas JV, Castro PHC, Rezende EC, Werneck FZ, Lima JRP. Relação entre o excesso de peso e a coordenação motora de jovens atletas de atletismo. Rev Bras Ciênc Esporte. 2017;39(1):91-7.

https://dx.doi.org/10.1016/j.rbce.2016.02.003

30. Luz LGO, Seabra AFT, Santos R, Padez C, Ferreira JP, Coelhoe-Silva MJ. Associação entre IMC e teste de coordenação corporal (KTK). Uma meta-análise. Rev Bras Med Esporte. 2015;21(3):230-5. https://dx.doi.org/10.1590/1517-869220152103144469

31. Caetano MJD, Silveira CRA, Gobbi LTB. Desenvolvimento motor de pré-escolares no intervalo de 13 meses. Rev Bras Cineantropom Desempenho Hum. 2005;7(2):9.

32. Chaves RN, Tani G, Souza MC, Santos D, Maia J. Variabilidade na coordenação motora: uma abordagem centrada no delineamento gemelar. Rev Bras Educ Fís Esporte. 2012;26(2):11. https://doi.org/10.1590/S1807-55092012000200012

33. Luz C, Cordovil R, Almeida G, Rodrigues LP. Link between motor competence and health related fitness in children and adolescents. Sports. 2017;5(2):E41. https://doi.org/10.3390/sports5020041

34. Han A, Fu A, Cobley S, Sanders RH. Effectiveness of exercise intervention on improving fundamental movement skills and motor coordination in overweight/obesechildren and adolescents: a systematic review. J Sci Med Sport. 2018;21(1):89-102. https://doi.org/10.1016/j.jsams.2017.07.001 